Original Article

\title{
Effects of high dilutions of Cymbopogon winterianus Jowitt (citronella) on the germination and growth of seedlings of Sida rhombifolia
}

\author{
Rosimar Maria Marques; Giuliani Grazyella Marques-Silva; \\ Carlos Moacir Bonato (PhD)
}

Department of Biology, State University of Maringá, Paraná, Brazil

\begin{abstract}
The effects of high dilutions of Cymbopogon winterianus (citronella) on the growth and germination of Sida rhombifolia are analyzed; 5 homeopathic dilutions $(3 \mathrm{cH}, 6 \mathrm{cH}, 12 \mathrm{cH}, 24 \mathrm{cH}$, $30 \mathrm{cH}$ ) and a control (water) were used, with 5 repetitions. Variables analyzed were the primary growth of the root system, length of the shoot, fresh mass total, germination percentage and germination speed index. All dilutions stimulated the primary growth of the root. Dilutions $3 \mathrm{cH}$, $6 \mathrm{cH}, 12 \mathrm{cH}$ and $\mathrm{cH}$ stimulated the growth of the aerial parts and $24 \mathrm{cH}$ inhibited it. Dilutions $6 \mathrm{cH}$, $12 \mathrm{cH}, 24 \mathrm{cH}$ and $30 \mathrm{cH}$ stimulated a larger production of fresh mass than $3 \mathrm{cH}$. Dilution $12 \mathrm{cH}$ resulted in the largest germination percentage while $24 \mathrm{cH}$ in the lowest. Dilution $12 \mathrm{cH}$ resulted in the highest score in the germination speed index, while $3 \mathrm{cH}$ and $24 \mathrm{cH}$ in the lowest.
\end{abstract}

Key words: Homeopathic dilutions; Plants; Germination; Growth; Cymbopogon winterianus; Sida rhombifolia

\section{Introduction}

As it is known, the formulation of the homeopathic therapeutic system was based on experimentation and observation of the effects of high dilutions of substances on healthy human beings. Experiments on plants developed in Europe, India, Mexico and Brazil have shown that high dilutions also elicit effects in plants [1]. Experimental research on healthy plants show the potential of high dilutions to influence the system and modify their dynamic patterns of behavior, manifested in an increase of defensive substances, photosynthesis, detoxification of aluminum and copper and alterations in the metabolism of plants [2-18]. These results indicate that homeopathic preparations may be useful from an agro-ecological perspective, as they favor sustainability and autonomy in the rural environment as well as the production of healthy food and environmental quality.

Sida rhombifolia L. is an invading seed-propagated species common in the southern region of Brazil. It develops in yearly and perennial cultures, orchards, gardens, pastureland and uncultivated plots; it competes highly with agriculture due to the development of deep root systems which may reach $50 \mathrm{~cm}$ deep with many secondary roots $[19,20]$.

Cymbopogon winterianus Jowitt, hailing from India and popularly known as citronella, is widespread in Brazil. It is a perennial herb which forms 1-meter high compact and strong clumps. Citronella has economical importance in the production of essential oils employed in the aromatic industry and as an insect repellant; furthermore, it has antimicrobial and acaricide properties [21]. More than 80 substances are comprised, from which citronellal $(40 \%)$, citronellol, geraniol, limonene and esters have particular importance [22-24].

According to Einhelling [25], alellochemicals may interfere in the metabolism of plants in several aspects, including growth, photosynthesis, enzymatic activity, protein synthsis, membrane permeability and transport. The present study aimed to verify the response of seedlings of $S$. rhombifolia to homeopathic dilutions of $C$. winterianus. 


\section{Materials and methods}

The study was conducted at the Homeopathy and Vegetation Physiology laboratory of the Department of Biology of the State University of Maringa.

The initial tincture was prepared from leaves of adult $\mathrm{C}$. winterianus collected in the morning from the botanic garden of the University in a proportion $1: 10(\mathrm{p} / \mathrm{v}), 1 \mathrm{~g}$ leaves $/ 10 \mathrm{~g}$ cereal alcohol $70 \%$. After 15-days maceration, the solution was filtered and the tincture was preserved in an amber flask. Homeopathic dilutions were prepared from this tincture following the Brazilian Homeopathic Pharmacopoeia (FHBII) [26]. The first dilution $(1 \mathrm{cH})$ was prepared adding $200 \mu \mathrm{l}(0.2 \mathrm{~mL})$ of tincture to $19.8 \mathrm{~mL}(1 / 100)$ distilled water with posterior succussion 100 times by mechanical arm dynamizer (Model Denise 50). Dilutions prepared were $3 \mathrm{cH}, 6 \mathrm{cH}, 12 \mathrm{cH}, 24 \mathrm{cH}$ and $30 \mathrm{cH}$. The flasks were cleaned and sterilized according to FHBII or cleaned with alcohol $70 \%$, boiled for 1 hour and dried on stove at $140^{\circ} \mathrm{C}$ for 1 hour.

Dormancy of S. rhombifolia seeds was interrupted through mechanical (lime) and thermal scarification by immersing the seeds in water at $100^{\circ} \mathrm{C}$ for 2 minutes. 20 seeds were distributed in Petri dishes (total $=600$ seeds) covered by Whatman\#1 filter paper imbibed with $5 \mathrm{~mL}$ of different homeopathic dilutions $(3 \mathrm{cH}, 6 \mathrm{cH}, 12 \mathrm{cH}, 24 \mathrm{cH}$ and $30 \mathrm{cH})$ and water (control) and distributed homogeneously in benches with light at room temperature for 7 days.

Variables essayed were: length of primary root and length of shoot by a graded ruler; increase of fresh biomass by analytic scale; percentage of germination and germination speed index (GSI). Only seeds with $2.0 \mathrm{~mm}$-long root protrusion were taken into account. Maguire's equation [27] was used to calculate GSI: GSI $=\mathrm{G}_{1} / \mathrm{N}_{1}+\mathrm{G}_{2} / \mathrm{N}_{2}+\mathrm{G}_{3} / \mathrm{N}_{3}+\ldots$ $\mathrm{G}_{\mathrm{n}} / \mathrm{N}_{\mathrm{n}}$, where $\mathrm{G}_{1}, \mathrm{G}_{2}, \mathrm{G}_{3}, \ldots \mathrm{G}_{\mathrm{n}}=$ number of seeds germinated on the day of observation and $\mathrm{N}_{1}, \mathrm{~N}_{2}$, $\mathrm{N}_{3}, \ldots \mathrm{N}_{\mathrm{n}}=$ number of days after seed planting.

The experiment design was totally randomized and included 5 repetitions. Data were analyzed by ANOVA and discriminated mean compared by Scott-Knott test at $5 \%$ probability (SAEG 5.0 ).

\section{Results}

S. rhombifolia responded to all dilutions regarding the length of primary root (Figure 1).

The increase in the length of primary root, which significantly differed from the control, shows the healthy state of the seedlings. Several experiments using homeopathic dilutions in seed germination and plant growth have also been reported [16,2832]. Following Lisboa et al. [33] it may be suggested that the information carried by homeopathic dilutions had an influence on the seedlings of $S$. rhombifolia physically expressed as an increase in the length of the primary root.

Figure 1: Effect of homeopathic preparation $C$. winterianus on the length of primary root (LPR) of $S$. rhombifolia seedlings with 5 solutions. (Mean followed by same letters does not differ statistically in Scott-Knott test at $5 \%$ probability).

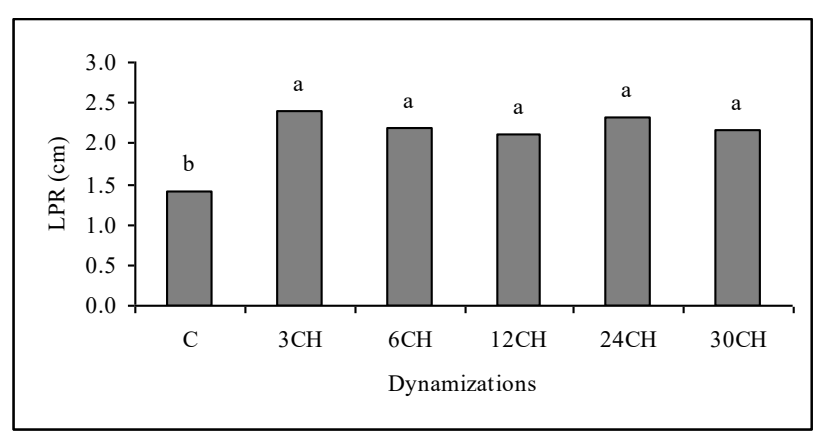

The length of shoots increased with dilutions $3 \mathrm{cH}$, $6 \mathrm{cH}, 12 \mathrm{cH}$ and $30 \mathrm{cH}$ by comparison to the control. Results were similar to those in the root system (Figure 2). The effect of dilution $24 \mathrm{cH}$ was not significantly different from the control's. These results are consistent with the notion of oscillation as a characteristic of high dilutions [34].

Figure 2:- Effect of homeopathic preparation $C$. winterianus on the shoot length (SL) of S. rhombifolia seedlings treated with 5 solutions. (Mean followed by the same letters does not significantly differ by Scott-Knott test at $5 \%$ probability).

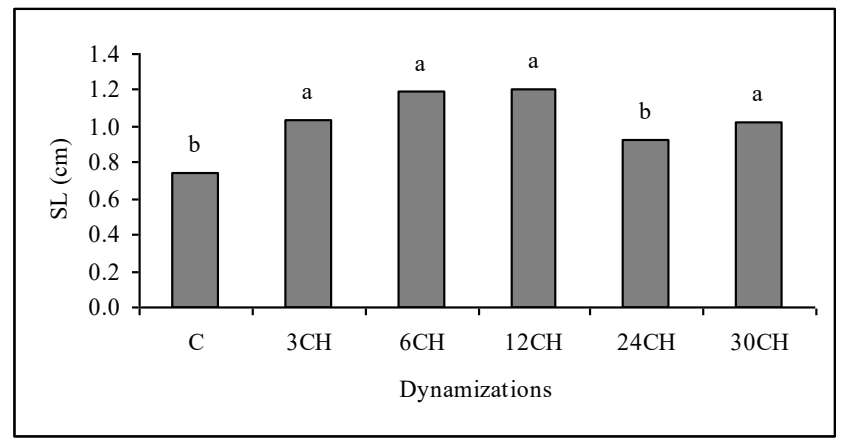

All dilutions but $3 \mathrm{cH}$ increased the production of fresh biomass regarding the control. (Figure 3) Although the mechanism(s) of action of high dilutions on plants are still not known, results suggest that somehow dilutions $6 \mathrm{cH}, 12 \mathrm{cH}, 24 \mathrm{cH}$ and $30 \mathrm{cH}$ increased the metabolic efficiency of the seedlings. 
Figure 3: Effect of homeopathic preparation $C$. winterianus on the increase of fresh biomass (FB) of $S$. rhombifolia seedlings treated with 5 solutions (Mean followed by the same letters does not differ statistically by Scott-Knott test at 5\% probability).

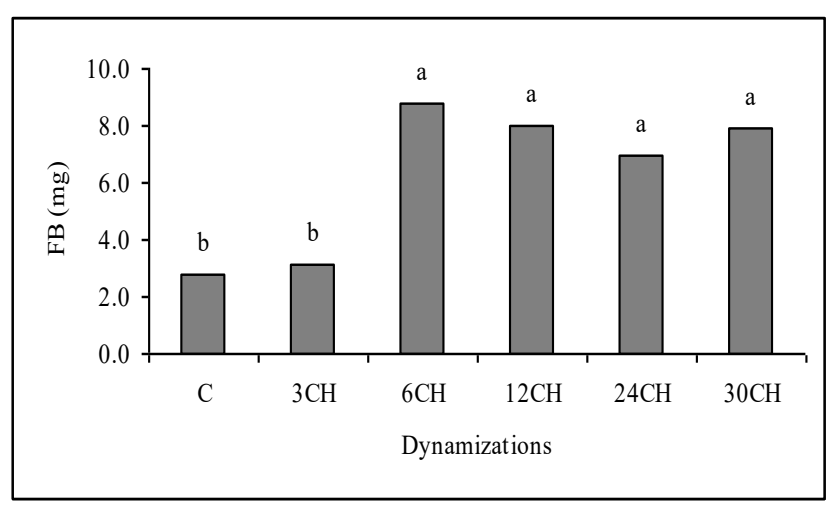

Germination percentage (GER) was affected by dilutions of C. winterianus. Dilutions $6 \mathrm{cH}, 12 \mathrm{cH}$ and $30 \mathrm{cH}$ had a higher effect than $3 \mathrm{cH}$ and $24 \mathrm{cH}$ (Figure $4)$.

Figure 4: Effect of homeopathic preparation $C$. winterianus on the percentage of germination (GER) of $S$. rhombifolia seeds treated with 5 solutions. (Mean followed by the same letters does not differ statistically by Scott-Knott test at $5 \%$ probability).

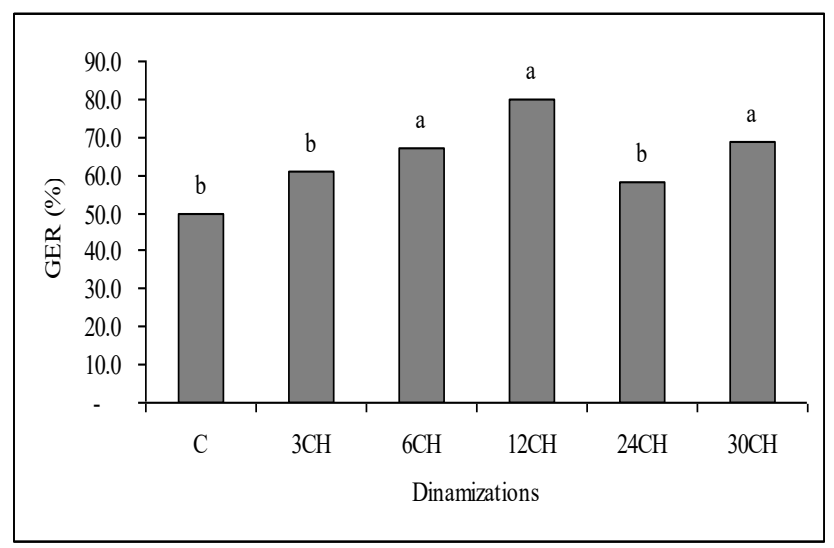

Other studies have shown that citronella in ponderal doses inhibit the germination of seeds, Craveiro and Mattos have suggested that the reason is its monoterpene contents. Our study, conducted with high dilutions of citronella obtained the opposite results. It may be suggested that dilutions $6 \mathrm{cH}, 12 \mathrm{cH}$ and $30 \mathrm{cH}$ activated some enzymes involved in endosperm store degradation and transport to the embryo during germination [35].

Experimental results indicate that GSI was affected by dilutions of $C$. winterianus. Dilutions $6 \mathrm{cH}, 12 \mathrm{cH}$ and $30 \mathrm{cH}$ were associated to a higher GSI, while dilutions $3 \mathrm{cH}$ and $24 \mathrm{cH}$ were not different from the control. (Figure 5) It may be thought that $C$. winterianus had an effect on the metabolism of the seeds of $S$. rhombifolia, intensifying enzyme reactions, the transport of metabolites, digestion of proteins, carbohydrates and lipids of the spare tissue for cellular elongation retaking and consequently of the emergence of radicles.

Figure 5: Effect of homeopathic preparation $C$. winterianus on germination speed index (GSI) in $S$. rhombifolia seeds, with 5 solutions. (Mean followed by the same letters does not differ statistically by Scott-Knott test at $5 \%$ probability).

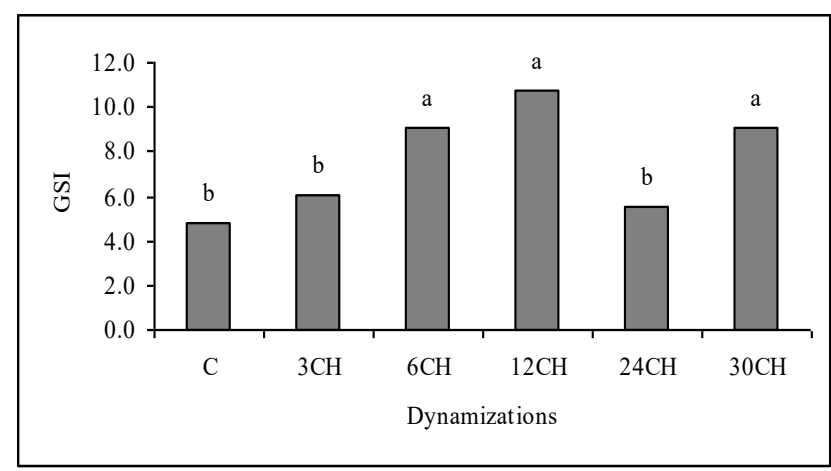

\section{Conclusions}

All 5 dilutions of $C$. winterianus increased the primary root of $S$. rhombifolia seedlings; all dilutions but $24 \mathrm{cH}$ elicited an increase in the aerial region. Seedlings exhibited a higher level of fresh biomass production under the influence of all dilutions but $3 \mathrm{cH}$. Regarding germination percentage, dilutions $6 \mathrm{cH}, 12 \mathrm{cH}$ and $30 \mathrm{cH}$ elicited a higher score, which was not observed with dilutions $3 \mathrm{cH}$ and $24 \mathrm{cH}$. Finally, the germination speed index was higher with dilutions $6 \mathrm{cH}, 12 \mathrm{cH}$ and $30 \mathrm{cH}$, which was not the case of dilutions $3 \mathrm{cH}$ and $24 \mathrm{cH}$.

These results indicate that homeopathic dilutions of C. winterianus have an effect on the germination and growth of S. rhombifolia. Moreover, that these effects have an oscillatory pattern, which is consistent with current conceptions of the particularities of the biological effects of high dilutions.

No mechanism of action may be still suggested for the biological effects of high dilutions in general and on plants, in particular. The results of this study suggest that several metabolic features of plants might be involved. Further studies are needed to confirm the experimental data, to assess the possible significance of their application in agronomy and to postulate mechanism(s) of action of high dilutions on plants. 


\section{References}

[1] Bonato CM. Homeopatia: fisiologia e mecanismo em plantas. Proceedings of the $4^{\circ}$ Seminário sobre Ciências Básicas em Homeopatia; 2004 Nov 14-16; Lages, Brazil. Lages: CAV/UDESC; 2004. 17-44.

[2] Casali VWD, Castro DM, Andrade FMC, Lisboa SP. Homeopatia bases e princípios. Viçosa: UFV/ DFT; 2006.

[3] Andrade FM, Casali VWD, Almeida AA. Preparados homeopáticos e adaptação de plantas em solo degradado. Proceedings of the $7^{\circ}$ Seminário Brasileiro sobre Homeopatia na Agropecuária Orgânica; 2006 Aug 6-7; Campos dos Goytacazes, Brazil. Viçosa: Universidade Federal de Viçosa; 2006. 217-238.

[4] Bonato CM. Homeopatia em modelos vegetais. Cultura Homeopática. 2007; 6(21): 24-28.

[5] Armond C. Indicadores químicos, crescimento e bioeletrografias de plantas de jambu (Acmella oleracea L.), capim-limão (Cymbopogon citratus (DC) Stapf) e folha-de-fortuna (Bryophyllum pinnatum (Lam.) Oken) submetidas a tratamentos homeopáticos [Thesis (Doctorate)]. Viçosa: Department of Phytotecnics. Federal University of Viçosa, UFV; 2007.

[6] Arruda VM. Aplicações de soluções homeopáticas em Achilleia millefolium L. (Asteraceae): abordagem morfofisiológica [Dissertation (Master)]. Viçosa: Departamento of Phytotechnics. Federal University of Viçosa, UFV; 2005.

[7] Peres PGP, Souza AF, Bonato CM. Efeito dos medicamentos homeopáticos Sulphur e Arsenicum album em algumas variáveis de crescimento de calêndula (Calendula officinalis L.). Proceedings of the $7^{\circ}$ Seminário Brasileiro sobre Homeopatia na Agropecuária Orgânica; 2006 Aug 06-07; Campos dos Goytacazes, Brazil. Viçosa: Universidade Federal de Viçosa; 2006. 91-182.

[8] Nunes RO. Teor de tanino em Sphagneticola trilobata (L.) Pruski com aplicação da homeopatia Sulphur [Dissertation (Master)]. Viçosa: Departamento f Phytotecnics. Federal University of Viçosa, UFV; 2005.

[9] Silva MRB. Assimilação de $\mathrm{CO}_{2}$ em plantas de Sphagneticola trilobata (L.) Pruski tratadas com preparados homeopáticos [Dissertation (Master)]. Viçosa: Departamento of Phytotechnics Federal University of Viçosa, UFV; 2005.

[10] Lisboa SP. Antagonismo de preparações homeopáticas na fotossíntese de plantas de Ruta graveolens (L.) [Dissertation (Master)]. Viçosa:
Departament of Phytotechnics, Federal University of Viçosa, UFV; 2006.

[11] Moretti MR, Rocha M, Bonato CM. Efeito de diferentes dinamizações homeopáticas de $\mathrm{AlCl}_{3}$ no comprimento da raiz principal de plântulas de milho. Proceedings of the XI Encontro Anual de Iniciação Científica. 2002; Maringá, Brazil. Maringá: Universidade Estadual de Maringá; 2002. 75 .

[12] Rocha M, Moretti MR, Bonato CM. Efeito de dinamizações de Sulphur no comprimento da raiz principal de plântulas de milho submetidas a estresse por alumínio. Proceedings of the $7^{\circ}$ Seminário Brasileiro sobre Homeopatia na Agropecuária Orgânica; 2006 Aug 06-07; Campos dos Goytacazes, Brazil. Viçosa: Universidade Federal de Viçosa; 2006. 81-89.

[13] Nitien G, Boiron J, Marin A. Ação de doses infinitesimais de sulfato de cobre sobre plantas previamente intoxicadas por essa substância; ação de uma $15^{\text {a }}$ centesimal hahnemanniana. In: Pesquisa experimental moderna em homeopatia. Rio de Janeiro: Editorial Homeopática Brasileira; 1969. 73-79.

[14] Almeida MAZ. Resposta do manjericão (Ocimum basilicum L.) a aplicações de preparações homeopáticas [Dissertation (Master)]. Viçosa: Departament of Phytotechnics, Federal University of Viçosa, UFV; 2002.

[15] Castro DM. Preparações homeopáticas em plantas de cenoura, beterraba, capim-limão e chambá [Thesis (Doctorate)]. Viçosa: Departament of Phytotechnics, Federal University of Viçosa, UFV; 2002.

[16] Bonato CM, Silva EP. Effect of homeopathic solution Sulphur on growth and productivity of radish. Acta Scientiarum Agronomy. 2003; 25: 259263.

[17] Silva MRB, Casali VWD, Bonato CM, Santos NT. Interaction Among $\mathrm{CO}_{2}$ Assimilation and Minutes Post-treatment of Sphagneticola trilobata with Apis mellifica $6 \mathrm{CH}$. Cultura Homeopática. 2006; 5(16): 48.

[18] Marques RM. Vigor de sementes de milho tratadas com os preparados homeopáticos Antimonium crudum e Arsenicum álbum [Dissertation (Master)]. Viçosa: Departament of Phytotechnics, Federal University of Viçosa; 2007.

[19] Lorenzi H. Plantas daninhas do Brasil: terrestres, aquáticas, parasitas e tóxicas. $3^{\text {rd }}$ ed. Nova Odessa: Instituto Plantarum; 2000. 
[20] Kissmann KG, Groth D. Plantas infestantes e nocivas. $2^{\text {nd }}$ ed. São Paulo: Basf; 2000.

[21] Marco CA, Innecco R, Mattos SH, Borges NSS, Nagao EO. Características do óleo essencial de capim-citronela em função de espaçamento, altura e época de corte. Hortic Bras. 2007; 25: 429-432.

[22] Matos FJA. Plantas medicinais: guia de seleção e emprego de plantas usadas em fitoterapia no Nordeste do Brasil. 2nd ed. Fortaleza: Imprensa Universitária; 2000.

[23] Costa LCB, Corrêa RM, Cardoso JCW, Pinto JEBP, Bertolucci SKV, Ferri PH. Secagem e fragmentação da matéria seca no rendimento e composição do óleo essencial de capim-limão. Hortic bras. 2005; 23: 956-959.

[24] Craveiro AA. Óleos de plantas do Nordeste. Fortaleza: Edições UFC; 1981.

[25] Einhelling FA. Mechanisms and modes of actions of allelochemicals. In: Putnam AR, Tang CS, editors. The science of allelopathy. New York: John Willey e Sons; 1986. 171-178.

[26] Farmacopéia Homeopática Brasileira. 2nd ed. São Paulo: Atheneu, 1997.

[27] Maguire JD. Speed of germination-aid in selection and evaluation for seedling emergence and vigor. Crop Sci. 1962; 2: 176-177.

[28] Betti L, Brizzi M, Nani D, Peruzzi M. A pilot statistical study with homoeopathic potencies of Arsenicum album in wheat germination as a simple model. British Homoeopathic J. 1994; 83(4): 195201.
[29] Betti L, Brizzi M, Nani D, Peruzzi M. Effect of high dilutions of Arsenicum album on wheat seedlings from seed poisoned with the same substance. British Homoeopathic J. 1997; 86: 86-89.

[30] Hamman B, Koning G, Him Lok K. Homeopathically prepared gibberillic acid and baret seed germination performance. Homeopathy. 2003; 92: $140-144$.

[31] Brizzi M, Lazzarato L, Nani D, Borghini F, Peruzzi M, Betti L. A biostatistical insight into the $\mathrm{As}_{2} \mathrm{O}_{3}$ high dilution effects on the rate and variability of wheat seedling growth. Forsch Komplementarmed Klass Naturheilkd. 2005; 12(5): 277-283.

[32] Tighe M. Homeopathy on cress-a pre-clinical method development using a simple plant growth model [Thesis (Doctorate)]. London: University of Westminster; 2005.

[33] Lisboa SP, Cupertino MC, Arruda VM, Casali VWD. Nova visão dos organismos vivos e o equilíbrio pela homeopatia. Viçosa: DFT/UFV; 2005.

[34] Bonamin LV. Dados experimentais que fundamentam teorias interpretativas sobre ultradiluições: tributo a Madeleine Bastide. Cultura Homeopática. 2007; 6(21): 29-35.

[35] Bewley JD, Black M. Seeds: physiology of development and germination. $2^{\text {nd }}$ ed. New York: Plenum; 1994.

\section{(cc) BY-NC-ND Licensed to GIRI}

Support: authors declare that this study received no funding

Conflict of interest: authors declare there is no conflict of interest

Received: 13 February 2008; Revised: 19 March 2008; Published: 31 March 2008

Erratum: 30 Dec 2008. (http://www.feg.unesp.br/ ojs/zacha_ijhdr/erratum/?v=7\&i=22\&pi=31)

Correspondence author: Carlos Moacir Bonato, cmbonato@uem.br, State University of Maringá, Brazil

How to cite this article: Marques RM, Marques-Silva GG, Bonato CM. Effects of high dilutions of Cymbopogon winterianus Jowitt (citronella) on the germination and growth of seedlings of Sida rhombifolia. Int J High Dilution Res [online]. 2008 [cited YYYY Mmm DD]; 7(22): 31-35. Available: http://www.feg.unesp.br/ ojs/index.php/ijhdr/article/view/208/342. 